Original Paper http://ajol.info/index.php/ijbcs http://indexmedicus.afro.who.int

\title{
Fish assemblages in the Upper part of the Volta River, Burkina Faso: A link analysis towards fisheries management and conservation
}

\author{
Komandan MANO $^{1,2^{*}}$, Adama OUEDA ${ }^{1}$, Raymond OUEDRAOGO ${ }^{4}$, Idrissa \\ OUEDRAOGO $^{1,3}$, Idrissa KABORE ${ }^{1}$, Gustave B. KABRE ${ }^{1}$ and Andreas H. MELCHER ${ }^{5}$ \\ ${ }^{1}$ Laboratoire de Biologie et Ecologie Animales (LBEA), Université Joseph Ki-Zerbo, Ouagadougou, Burkina \\ Faso, 03 BP 7021 Ouagadougou 03. \\ ${ }^{2}$ Université de Dédougou, Burkina Faso, BP 176 Dédougou, Burkina Faso. \\ ${ }^{3}$ Centre Universitaire Polytechnique de Dori, Burkina Faso/Université Ouaga 2, 12 BP 417 Ouagadougou 12, \\ Burkina Faso. \\ ${ }^{4}$ Département de Productions Forestières, Institut de l'Environnement et de Recherches Agricoles (INERA), 04 \\ BP 8645 Ouagadougou 04, Burkina Faso. \\ ${ }^{5}$ Centre for Development Research, BOKU - University of Natural Resources and Life Sciences, Dänenstrasse 4, \\ 1190 Vienna, Austria. \\ *Corresponding author; E-mail: manokomandan@yahoo.fr; phone: +226 70172422.
}

\section{ACKNOWLEDGEMENTS}

We are grateful to APPEAR programme (Austrian Partnership Programme in Higher Education and Research for Development), funded by the ADA (Austrian Development Agency) and implemented by the OEAD (Austrian Agency for International Cooperation in Education and Research) for funding this study.

\begin{abstract}
The insufficiency of information on fish assemblages has limited the ability to carry out effective conservation measures, hence failing to address economic and ecological roles of fish. Therefore, the present study aimed at characterizing the fish community in the upper part of Volta River basin and drawing up their influence on fisheries' sustainability. From 2009 to 2014, fish individuals were collected in nine sampling areas belonging to the Volta catchment, mainly in the catchment of Nakanbé and Mouhoun rivers that are the two major tributaries. More than 40,000 fish specimens were collected in over 600 mesohabitats by using several types of fishing gears (gill nets, cast nets, long lines and electric fishing gears). Altogether, 79 fish species belonging to 41 genera grouped in 19 families were identified. The most common species were Enteromius macrops (50.71\%), Brycinus nurse (35.32\%), Enteromius ablabes, Oreochromis niloticus (47.10\%), Sarotherodon galilaeus (47.88\%) and Coptodon zillii (42.23\%). The fish species richness varied according to the sampling area. The main trend is that the protected area of Nazinga is the most diverse thus would be regarded as an appropriate refuge for fish species.
\end{abstract}

(C) 2019 International Formulae Group. All rights reserved.

Keywords: Common species, species richness, protected area.

\section{INTRODUCTION}

Aquatic ecosystems are inhabited by heterogeneous groups of animals. Among this huge aquatic fauna, fish is by far the most important group for human alimentation. It has colonized various aquatic ecosystems such 
as brackish water, marine water and freshwater (Froese and Pauly, 2019). The latter is housing a high proportion of fish density. Each continent holds a diverse freshwater fish fauna but the distribution patterns are the result of physical barrier effects, past fish dispersal, as well as the adaptation to physical and chemical parameters.

In the West African sub-regional level, the fish fauna is fairly well known as many studies investigated the fish diversity, fish reproduction and feeding, fish ecology and parasite fauna (Lalèyè et al., 2004; Quarcoopome et al., 2011). In this part, fish fauna studies are supported by a large-scale compiled data collection (Paugy et al., 2003a, b; Froese and Pauly, 2019).

In Burkina Faso, the fish species have been studied in the recent years. However, these studies were mainly oriented on fish parasitology and diet (Kabré et al., 2002; Ouéda et al., 2008; Boungou et al., 2013). More recently, few researchers investigated fish biology (Da et al., 2018; Ouédraogo et al., 2019). As consequence, little information is available on the diversity and status of fish assemblages. This deficiency of information on fish assemblages has limited opportunity to evaluate fisheries and ability to carry out effective conservation measures, hence failing to address economic and ecological roles of fish. The most cited reference for Burkina Faso fish assemblages is Roman (1966) who, after investigating the Upper Volta and compiling many sources, came up to a list of 121 fish species. The other reference document comes from the monitoring program on Onchocerciasis (OCP), a regional project that prospected different West African streams (Paugy et al., 1999). A list of 123 fish species grouped under 28 families and 63 genera have been published for Burkina Faso in Fish Base (Froese and Pauly, 2019).

However, taxonomic revisions in some families (Alestidae and Mormyridae), loss of specific habitats and increasing human impacts on water bodies combined to the low academic level (grey literature) of the available works have made difficult the use of these data for management purposes. Ouédraogo Raymond, was one of a few Burkinabe researchers to examine the relationships between fish fauna and human within the country (Ouédraogo, 2010; Melcher et al., 2012). Currently, one believes that there is less species than the list stated and an update is urgently needed. Therefore, by characterizing fish community in the Upper Volta basin and drawing up their influence on fisheries' sustainability, this study increases the reliable information on fish and fisheries in Burkina Faso.

\section{MATERIALS AND METHODS Study Area}

Burkina Faso is a landlocked country drained by three international rivers that are: the Volta covering $64 \%$ of the country total area; the Niger $(30 \%)$ and the Comoé $(6 \%)$. The Volta River consists of three major tributaries that are: the Mouhoun, the Nakanbé and the Nazinon (respectively former Black, White, and Red Volta) which finally all flow into Lake Volta in Ghana. The Nakanbé is an intermittent river and is highly impounded to store water for human and animal use (Cecchi et al., 2007). Its sub-basin contains nearly $50 \%$ of national population (Cecchi et al., 2007) and hosts more than 100 inhabitants per square kilometer. The Mouhoun River covers the largest part of the country $\left(92,000 \mathrm{~km}^{2}\right)$ and is rarely dry. It rises in the south of the country, flows firstly toward North through the area of Bobo-Dioulasso where the precipitation exceeds $1,000 \mathrm{~mm} / \mathrm{year}$, then turns suddenly and flows towards the south across the country and later forms the Burkina-Ghana frontier. The country has a tropical climate with two seasons: a rainy season that lasts from May to October and a dry season lasting from November to April. The high temperature (up to $45^{\circ} \mathrm{C}$ ) results in a massive water loss due to the high evaporation rates of more than $2000 \mathrm{~mm}$ /year (Ouédraogo, 2010). Since the two waves of severe droughts that Burkina Faso experienced in the 70's and 80 's, the numbers of small to large size reservoirs increased exponentially. More than 
1,500 man-made lakes have been constructed (Cecchi et al., 2007). This increased the water availability that is used for any purpose and in addition constitutes a refuge for aquatic animals, particularly fish species. This may also affect fish species richness and their abundances.

The study survey extends between the Sourou valley in the Northwest, the Boura reservoir in the Southwest (border of Ghana) and Bagré reservoir in the Southeast. Fish data were collected between 2012 and 2014 and was supplemented with data previously collected between 2008 and 2009. Sampling areas are located in Nakanbé and Mouhoun sub-basins in the Upper Volta, Burkina Faso. They were selected by a consortium of scientists from Universität für Bodenkultur Wien and Université Joseph Ki-Zerbo (former Université de Ouagadougou), the local fishermen, the Ministry in charge of the environment, the General Directorate of Fisheries and Aquaculture and the Programme of the IUCN for Burkina Faso. The decisive criteria for selections were the water availability, the accessibility, the different human stressors, the spatial variability, the security issues and travelling costs (Susfish, 2014). A total of nine study areas were selected. They were: Boura, the ranch of Nazinga, Koubri (two areas) (Koubri and Koubri_free), Kougri, Wayen, Bagré, Bobo and Sourou. Each area was further subdivided into different sites. A site is the entity of all nearby and accessible mesohabitats. Due to its high impoundments, the area of Koubri was split into two areas: Koubri (zone highly impounded) and Koubri_Free (zone without barriers). In Figure 1, an overview of the sampling areas location is given. In total, 637 sampling occasions (mesohabitats) were taken in 72 sampling sites.

\section{Data Collection \\ Fish sampling}

Fish were sampled using cast net $(\mathrm{CN})$, gill net (GN), long line (LL) and electric Generator. Different fish species live in different areas of the water column, in various lotic, lentic small and large water bodies, and behave in various ways. As a result, using different gear types will probably increase the fish diversity in the sample. For Electric Fishing the backpack-generator ELT60-IIH from Hans Grassl was applied. The generator has $1.3 \mathrm{~kW}$ and $500 \mathrm{~V}$ and was always performed by wading. The small water bodies were fished completely, while the big ones were point-sampled. Two professional commercial fishermen were recruited to conduct the CN, GN and LL fishing methods. Most of the time the fishermen were wading but they used a canoe for some deeper areas. The fish species were identified thanks to Paugy et al. (2003a, b) and their total lengths were measured to the nearest millimeter. The specimens of questionable species names were measured, sacrificed and fixed in $70 \%$ alcohol. Their species were identified later in the Laboratoire de Biologie et Ecologie Animales (LBEA) of the Universite Joseph KI-ZERBO, Burkina Faso. Those that could not be identified there were sent to Royal Museum of Central Africa, Tervuren, Belgium. Voucher specimens of fish were also brought to the LBEA for species collection.

\section{Formulation of used ecological guilds}

Guilds analysis is a commonly applied approach used to describe trophic structure and feeding interactions within complex animal communities. We grouped collected fish species into guilds, each of which denotes some ecological attributes (Root, 1967). Whereas, guilds classification encompasses all forms and functions of fish, in this study we investigated reproductive guilds and feeding guilds which are important variables for resources exploitation (Balon, 1975). The information about the reproduction and feeding habits were drawn from many sources, mainly Lévêque and Paugy (2006); Albaret (1982); Paugy (1980), Paugy et al. (2003a, 2003b). Data were also retrieved from FishBase, a global database including more than 34000 fish species inhabiting freshwater brackish and marine ecosystems (Froese and Pauly 2019). 


\section{Reproductive guilds}

We formulated this group in reference to spawning times of fish by year: single spawners (one laying in the year) and fractional spawners (multiple laying). All fish belonging to group "single spawners" lay one time a year. Most of the time at the beginning of the rainy season during which food is expected to be abundant due to water flow from rainfall. "Fractional spawners" group encompasses specialized fish species which release eggs several times during the year. Fish species belonging to this group were adapted to have multiple lay in a year. Some of these species lay continuously while others lay during specific periods in the year.

\section{Feeding guilds}

Fish were classified according to their feeding habits. Five groups were constructed namely: omnivorous, herbivorous, invertivorous, limnivorous and piscivorous.

\section{Data Analysis}

The fish assemblage was analyzed using presence/absence and abundance data. The biotic diversity such as fish species richness, genera richness and family richness were respectively taken as the count number of species, genera and families in the sample based on the presence/absence matrix. The relative abundance was determined to give an overview of species dominance in the all sample and throughout the Sample areas.

The regularity of fish species in the samples is an important tool to measure specific fish species' rarity and commonness. It is estimated by occurrence rate $(\mathrm{F})$, and used to evaluate fish assemblages' composition in the all sample and throughout sample sites. $\mathrm{F}$ is calculated on the basis of presence/absence matrix using the following formula:

$$
\mathbf{F}=\frac{\mathrm{n} * 100}{\mathrm{~N}}
$$

$\mathrm{N}=$ total number of samples;

$\mathrm{n}=$ number of samples in which the considered species is recorded.

For visualization, pie charts and bar charts and Venn diagram were used to present fish fauna composition. All analysis and graphs were performed using SPSS, version 21 and R 3.3.3.

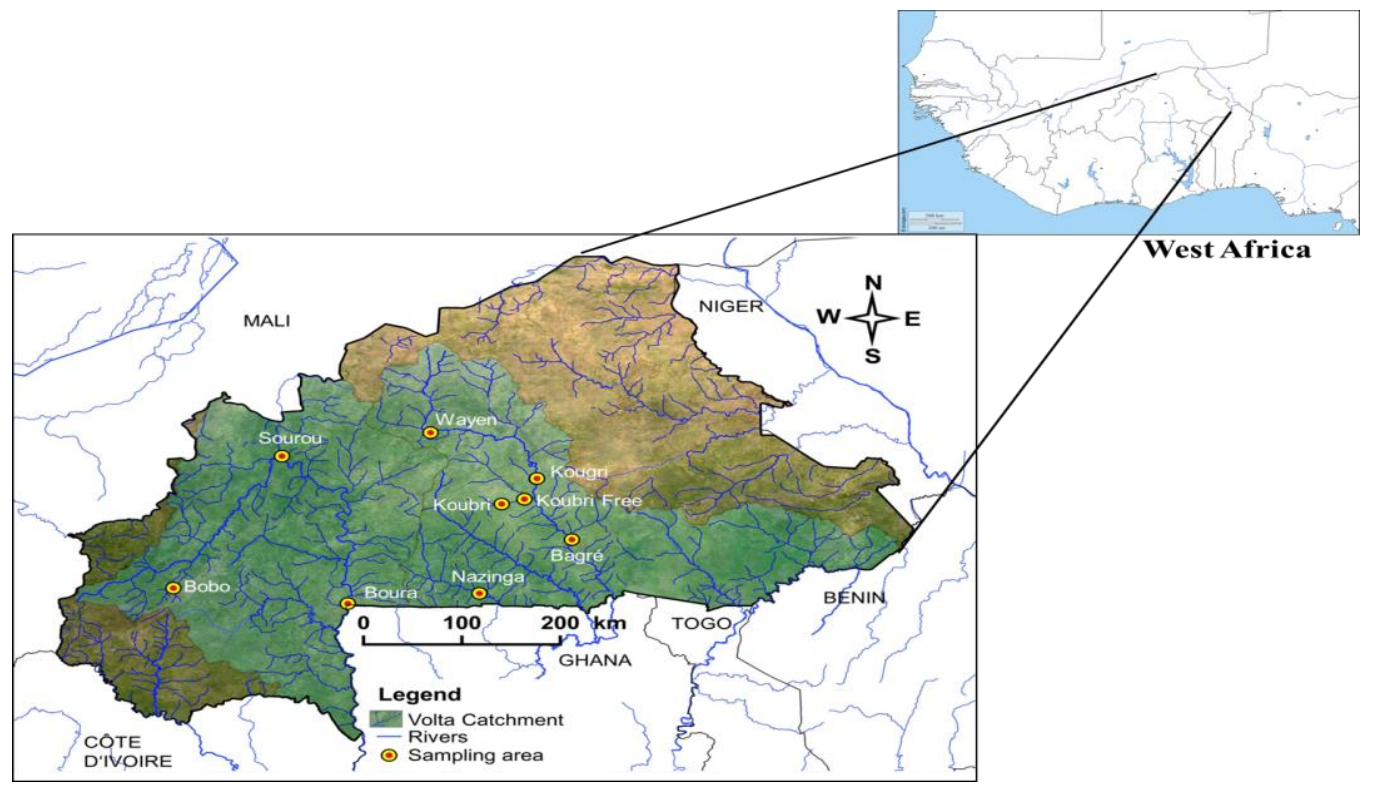

Figure 1: Map of the Volta catchment in Burkina Faso and distribution of sampling areas (adapted from Cecchi et al., 2007). 


\section{RESULTS}

\section{Fish assemblage's structure}

Altogether 44,788 fish individuals were collected in the 9 sampling areas belonging to the Upper Volta catchment (6 in the Nakanbé basin and 3 in the Mouhoun one). A total of 79 fish species belonging to 41 genera and 19 families were recorded (Table 1). The Alestidae family had the highest species richness (14 species). It was followed respectively by the Cyprinidae and the Mormyridae (12 species each one), the Mochokidae ( 9 species), the Cichlidae (6 species), the Schilbeidae and the Clariidae (4 species each one), the Claroteidae ( 3 species) and the Anabantidae, the Bagridae, the Distichodontidae and the Polypteridae families (2 species each one). However, 7 families were monospecific and were listed as: Latidae (former Centropomidae), Malapteruridae, Protopteridae, Arapaimidae (former Osteoglossidae), Channidae, Citharinidae and Gymnarchidae.

The fish community is dominated mainly by two families (Figure $2 \mathrm{~A}$ ) which totalized together more than half of all fishes: Cyprinidae ( $41 \%$ of total individuals) and Cichlidae (23\% of total individuals). The Alestidae counts for $11.5 \%$ of total individuals and the Mormyridae, Schilbeidae, Clariidae and Mochokidae ranged between 3 and less than $10 \%$ each. All the other families occurred in lower abundances and contributed all together for less than $5 \%$ of the total individuals. Out of the 79 recorded species, the most dominant species were Enteromius macrops (18.6\%), Enteromius ablabes (14.2 $\%)$, Sarotherodon galilaeus (9.4\%); Brycinus nurse (6.5\%); Oreochromis niloticus (5.5\%), and, Coptodon zillii (5\%) as illustrated by Figure $2 \mathrm{~B}$.

The species number and their relative abundances according to their reproductive and trophic guilds are summarized in Figure 3. Most species spawn in a specific period of the year. But in term of abundance, Burkina fish faunal was dominated by multiple laying fish species (about $3 / 4$ of total individuals) (Figure 3 B).
Regarding the trophic guilds, invertivorous species predominated in number of species (38 species) and abundances (37\% of total individuals). However, herbivorous fishes with only 5 species totalized $20 \%$ of catch individuals while piscivorous fishes with 17 species included few individual numbers (Figure 3 A). Limnivorous fishes were less represented in number of species and individuals.

\section{Fish species frequency of Occurrences}

The analysis of fish species occurrences in Burkina Faso indicated that the fish community is composed of a fixed base of twelve species present in each sampling area: Brycinus nurse, Coptodon zillii, Marcusenius senegalensis, Enteromius macrops, Clarias anguillaris, Hemichromis fasciatus, Oreochromis niloticus, Pollimyrus isidori, Polypterus senegalus, Sarotherodon galilaeus, Schilbe intermedius and Synodontis schall. However, five of aforementioned species recorded an occurrence rate ranging between $25 \%$ and $50 \%$ thus can be considered as the common fishes in the Burkina Faso part of the Volta River (Table 2): Enteromius macrops, Sarotherodon galilaeus, Oreochromis niloticus, Coptodon zillii and Brycinus nurse. Conversely, 73 of the species have an occurrence rate less than $25 \%$ and relative abundance rate less than $5 \%$ each. Moreover, 23 species of them have an occurrence rate less than $1 \%$ per each group.

Among the large numbers of species in Burkina Faso, only a few species are considered abundant and well widespread. The majority of fish are less represented in the water bodies. More than a quarter of the recorded fish species are rare.

\section{Fish Assemblages variability Across Sampling Areas}

The sampling areas had shown varied species richness that ranged from 19 to 58 species. The number of exclusive species encountered in this study ranged from 0 to 10 .

Out of the 79 found species, 16 occurred in one sampling areas, with no 
reappearance at any other place. From the aforementioned 16 species, ten appeared exclusively in Nazinga, two in Kougri, two in Sourou, one in Koubri_Free and one in Bobo. No species appeared exclusively in the other areas i.e. Koubri, Boura and Wayen.

Nazinga showed the highest species richness (58 species), followed by Koubri_Free and Kougri (49 fish species each), while Wayen exhibited the lowest species richness.

In Figure 4, a fish community overview throughout Nakanbé River sampling areas is given. Sixteen species could all be found at Koubri_Free and Kougri areas, but absent in Koubri. All the four sampled areas shared in common 28 fish species. Kougri, Koubri_Free and Koubri had exhibited respectively three, two and one exclusive species. While all species caught in Bagré were found in the others areas.

An overview of the species composition in Bagré, Koubri, Koubri_Free, Kougri and Nazinga showed that 25 fish species were common to all these areas. However, a total of 19 exclusive fish species were recorded: 15 caught exclusively in Nazinga, two in Kougri, one in Koubri_Free and one in Koubri (Figure 5).

Table 1: Overview of families, including number of genera and species for the whole study area.

\begin{tabular}{cccc}
\hline $\mathbf{N}^{\circ}$ & Family name & Number of Genera & Number of Species \\
\hline 1 & Alestidae & 5 & 14 \\
2 & Cyprinidae & 4 & 12 \\
3 & Mormyridae & 1 & 12 \\
4 & Mochokidae & 4 & 9 \\
5 & Cichlidae & 2 & 6 \\
6 & Clariidae & 3 & 4 \\
7 & Schilbeidae & 2 & 4 \\
8 & Claroteidae & 1 & 3 \\
9 & Anabantidae & 1 & 2 \\
10 & Bagridae & 2 & 2 \\
11 & Distichodontidae & 1 & 2 \\
12 & Polypteridae & 1 & 2 \\
13 & Arapaimidae & 1 & 1 \\
14 & Channidae & 1 & 1 \\
15 & Citharinidae & 1 & 1 \\
16 & Gymnarchidae & 1 & 1 \\
17 & Latidae & 1 & 1 \\
18 & Malapteruridae & 41 & 1 \\
19 & Protopteridae & TOTAL & 1 \\
& & & 1 \\
\hline
\end{tabular}




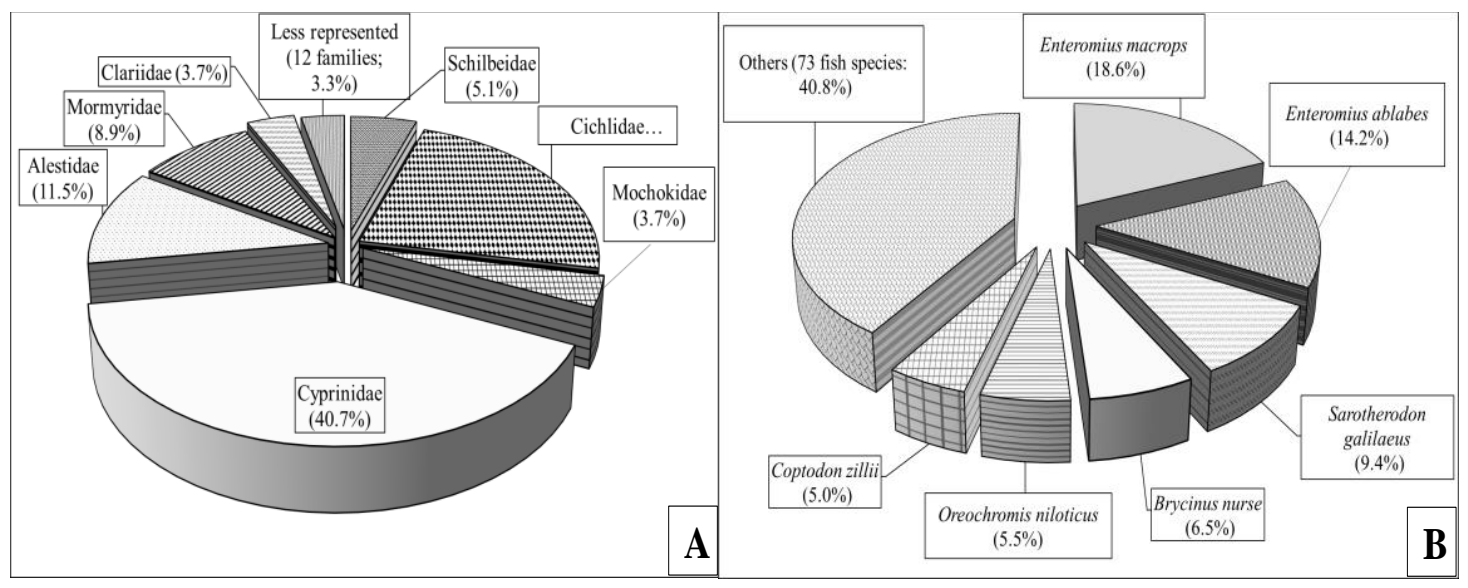

Less represented families $=$ families with less than $1 \%$ of total individuals, others $=$ fish species with relative abundance less than $5 \%$ each.

Figure 2: Fish community repartition in the sample (families' relative abundances (A) and species' relative abundances $(\mathrm{B})$.

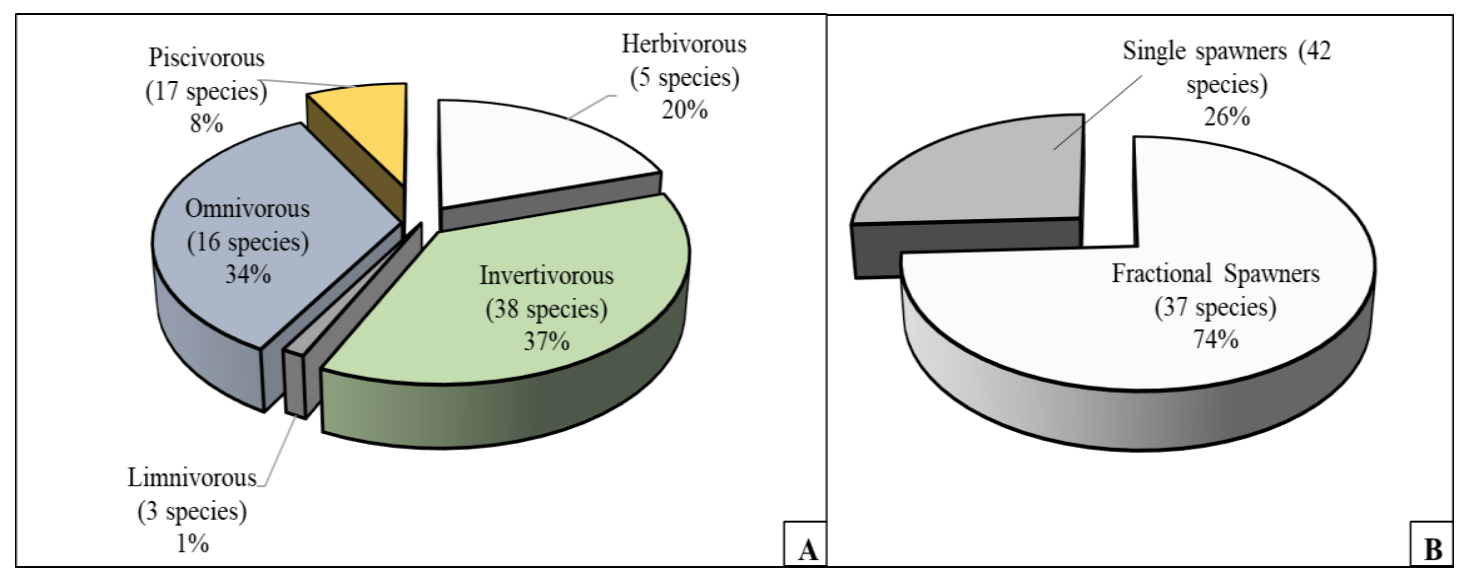

Numbers in bracket refer to species richness and percentages refer to individuals' relative abundances.

Figure 3: Adult trophic (A) and reproductive strategies (B) of collected fish.

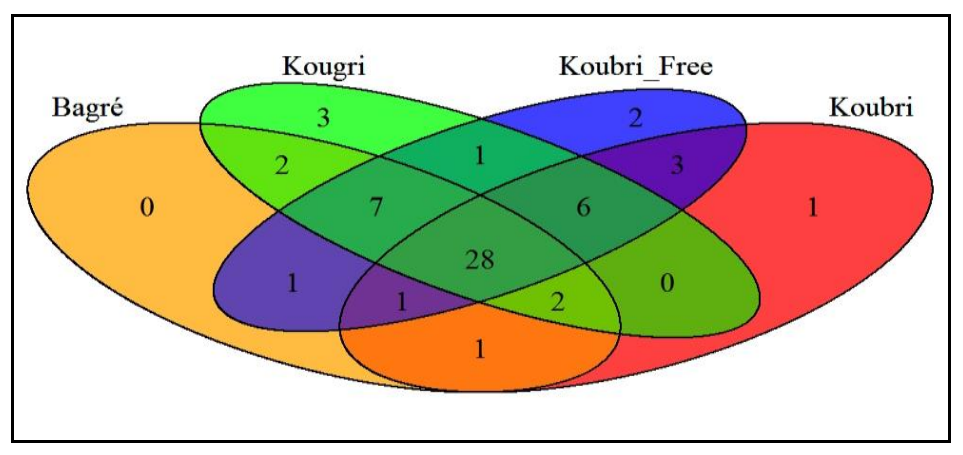

Figure 4: Venn diagram summarizing species richness in the study areas of the Nakanbé basin and the number of common and exclusively fish species between them. 
Table 2: Occurrence rate of fish species.

\begin{tabular}{|c|c|}
\hline $\begin{array}{c}\text { Fish species } \\
\quad(N=79)\end{array}$ & $\begin{array}{c}\text { Occurrence rate }(\%) \\
(\mathrm{N}=637 \text { samples })\end{array}$ \\
\hline Enteromius macrops & 50.71 \\
\hline Sarotherodon galilaeus & 47.88 \\
\hline Oreochromis niloticus & 47.10 \\
\hline Coptodon zillii & 42.23 \\
\hline Brycinus nurse & 35.32 \\
\hline Synodontis schall & 21.19 \\
\hline Clarias anguillaris & 21.04 \\
\hline Enteromius ablabes & 18.37 \\
\hline Schilbe intermedius & 17.58 \\
\hline Hemichromis bimaculatus & 16.95 \\
\hline Clarias gariepinus & 14.91 \\
\hline Marcusenius senegalensis & 14.44 \\
\hline Chelaethiops bibie & 13.34 \\
\hline Rhabdalestes & 12.72 \\
\hline Lates niloticus & 12.40 \\
\hline Hemichromis fasciatus & 10.36 \\
\hline Others (63 fish species) & Occurrence $<10 \%$ each \\
\hline
\end{tabular}

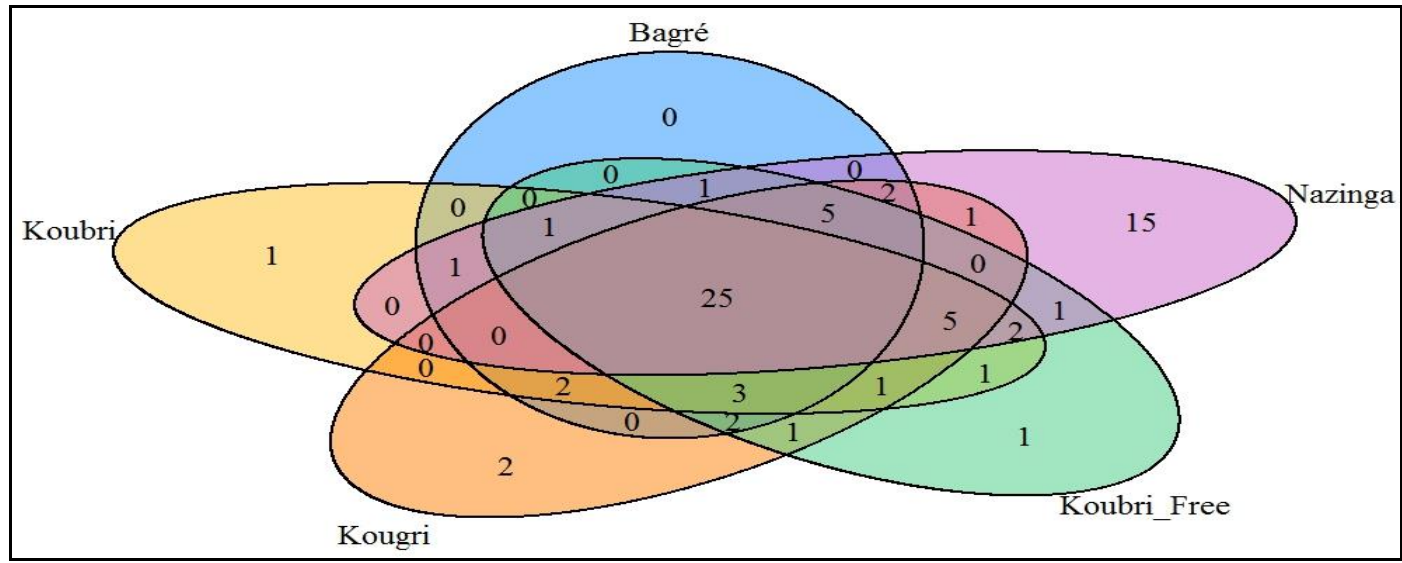

Figure 5: Venn diagram summarizing species richness in areas belonging to Nakanbé catchment and the number of common and exclusively fish species between them.

\section{DISCUSSION}

Any important point to be considered in the study of a fish community is to establish the species list. In the present study, we recorded 79 fish species regrouped into 41 genera and 19 families. The study of fish species that covered so large area of Burkina Faso is old. It is referred as Roman (1966) that after sampling fish and compiling the results and previous studies listed 121 species in the upper part of the Volta. Fish base has mentioned that 123 fish species exist in 
Burkina Faso (Froese and Pauly, 2019). The reasons why we have a low number of species recorded in the current study are unclear. But the species may have declined since that study, due to the river course obstructions by damming and other causes. Actually, more than $80 \%$ of the 1500 reservoirs of the country were built in the 70s and after (Cecchi et al., 2007; Boelee et al., 2009). Almost no reservoir has fish pass system as we observed during the survey. This fact may impede fish migration along the river course as reported by Leirmann et al. (2012). Negative effect of dams on fish species richness was previously reported worldwide (Vörösmarty et al., 2010). The probable erosion of fish diversity could also be the effect of other human activities such as agriculture developed along reservoirs (Cecchi et al., 2007) which obstructed fish favourable habitats (Leirmann et al., 2012) or overfishing, which extirpated some fish species. This statement is justified by the fact that the highest number of exclusive species was recorded in the protected area Nazinga.

Quantitative and qualitative analysis on fish faunal showed that Cichlidae, Cyprinidae, Mormyridae, Alestidae and Mochokidae families contained more species number and dominated in our catches. Many studies have documented the dominance of these families in West African rivers (Lalèyè et al., 2004; Montchowui et al., 2008). They constitute the characteristics of the Nilo-Sudanian ichthyological province (Lévêque and Paugy, 2006). The fish family with highest dominance in abundance was the Cyprinidae. This finding agrees with the work of Sirima et al. (2009), which reported that the Cyprinidae and the Mormyridae were the most dominant fish in Comoé another river basin of Burkina Faso. The higher abundance of Mormyridae in Comoé could be attributed to the environment of the study area, which is a protected area with almost natural conditions. Our findings were in contrast with the results found by Ouédraogo et al. (2016a, b) respectively in Boalin (center of Burkina Faso) and Higa (north of Burkina Faso) where the fish community was dominated by the Cichlidae family. This difference could be associated with the various fishing methods that were used. Our catch was dominated by dwarf
Cyprinidae such as Enteromius captured mostly with electric fishing, while this fishing method was not used by Ouédraogo et al. (2016a, b) in their two studies. The high abundances of dwarf species could be explained by their small sizes, which allow them to escape through the mesh of fishing gears used by fishermen mainly consisted of gill net, cast net and long line. Moreover, their capacity to take advantage in seasonal water bodies and topographic roughness may have favoured their widely expansion (Melcher et al., 2012). The Cichlidae family was the next most abundant. The members of this family present many advantages among others: the early maturity, the ability to utilize a wide range of food in the lower trophic level as herbivores, the parental care, the rapid colonization as well as high environmental tolerances (Lévêque and Paugy, 2006; Sirima et al., 2009). These attributes have been considered critical for facilitating successful invasion by the cichlidae species in water bodies and they are largely believed to be the most abundant fish family in West Africa due to their enduring ability to withstand low dissolved oxygen level (Lévêque and Paugy, 2006; Witte et al., 2012).

More than one third of the recorded fish species were poorly represented in our catch (less than 50 individuals in the total catch); they occurred rarely and in limited number. Some of these poorly represented species are also rare in other rivers of the Nilo-Sudanian ichthyological province, while some other species from the group are considered to be well represented. From this group, Brycinus longipinnis represented more than $20 \%$ of fish individuals recorded in upper and middle course of River Nero in Côte d'Ivoire (N'Zi et al., 2015). Fish families such as Anabantidae, Arapanidae, Bagridae, Citharinidae, Distichodontidae, Gymnarchidae, Latidae, Malapteruridae, Polypteridae and Protopteridae were rare in the catch. They were also rare in other water bodies of Burkina. For instance, Gymnarchus niloticus was formerly recorded in Koubri and Bagré (Baijot et al., 1994), the two sampling areas that we also visited during our study. 
We did not capture one individual from this family under the framework of this study. Nevertheless, none species of the abovementioned families was classed as threatened according to IUCN.

In regard of the fish communities from our surveyed sampling areas, the results showed that the Nazinga area differed significantly from the others. It was associated with the greatest species diversity as well as the highest numbers of exclusive species. This suggests favourable conditions for fish, which could be justified by the protected status of this area and thus result in minimized human impacts on water bodies (Ouédraogo, 2010; Melcher et al., 2012; Meulenbroek, 2013; Stranzl, 2014; Kaboré, 2016). We found that fish communities were similar between Koubri, Koubri_Free, Kougri and Bagré although the species richness was higher in Koubri_Free and Kougri. Such similarities were expressed with Venn diagram. The low species richness and the absence of exclusive species in Bagré (located in downstream Nakanbé) in comparison to Kougri, Koubri_Free can be explained by three factors. Firstly, Bagré area is located in the downstream Nakanbé and is isolated from its downstream section by the dyke of Bagré reservoir which probably impedes fish migration from Volta Lake in Ghana and Nakanbé in Burkina Faso. Secondly, the absence of barriers on the Nakanbé main course between Bagré and Ziga may favour fish migration from down- to upstream Nakanbé, especially early rainy season (Melcher et al., 2012) which enabled fish exchange between areas located in this section. Thirdly, the seasonality of the Nakanbé River which leads to water flow interruption at the end of rainy season and prevent fish species from returning back. Regarding the decrease of species richness from Kougri and Koubri_Free to Koubri, that suggested impact on fish migration since Koubri was characterized by high presence of dams.
Regarding the adult trophic guilds, the omnivore, invertivore and herbivore fishes were well represented. As a consequence, the food web in the Burkinabe water bodies seems well exploited. This fact suggests that fisheries are not impacted due to dietary shift. However, the high proportion of invertivore fishes may present a risk for fisheries since several studies showed positive correlation between carnivorous fishes (invertivore and piscivore) and bioaccumulation (Pouilly et al., 2012; Ouédraogo and Amyot, 2013). In the context of Burkina Faso, a country in which temporary water bodies are dominating, a high proportion of fish with multiples laying in the year may ensure fisheries sustainability.

\section{Conclusion}

The decrease of fish species number combined with dominance of intolerance and dwarf fishes as well as hydro-morphological alterations represent a proof that fish assemblages of Burkina Faso would exhibit features of depletion. However, investigation on trophic and reproductive guilds suggested a sustainable fishery feature but more attention should be paid due to the high proportion of carnivorous fishes which could represent a potential source of bioaccumulation.

\section{COMPETING INTERESTS}

The authors declare that they have no competing interests.

\section{AUTHORS' CONTRIBUTIONS}

$\mathrm{KM}$ and IO conceived and designed the study under the supervision of $\mathrm{AO}$ and RO. KM and IO performed the fieldwork. Data analysis and manuscript editing were done by KM assisted by IO, AO and RO. All the work was done under the supervision of GBK and AHM.

\section{ACKNOWLEDGMENTS}

We thank anonymous reviewers for many insightful comments and suggestions which largely helped to improve the 
manuscript. This study was performed as a part of the APPEAR-sponsored SUSFISH Project (Sustainable Management of Water and Fish Resources in Burkina Faso, www.susfish.boku.ac.at) that aimed to "strengthen in-country capacities for science, policy and practice to establish the basis for sustainable fisheries in Burkina Faso. It received the support of the follow-up project SUSFISH-Plus. We would like to express our grateful to all partners of these projects.

\section{REFERENCES}

Albaret J-J. 1982. Reproduction et fécondité des poissons d'eau douce de Côted'Ivoire. Rev. Hydrobiol. Trop., 15: 347371.

Baijot E, Moreau J, Bouda S. 1994. Aspects hydrobiolgiques et piscicoles des retenues d'eau en zone soudanosahélienne. Ede ; Bruxelles. Centre Technique de Coopération Agricole et Rurale (CTA); Commission des Communautés Européennes (CEE), 1994, 250p.

Balon EK. 1975. Reproductive guilds of fishes: A proposal and definition. $J$. Fish. Res. Board., 32: 821-864.

Boelee E, Cecchi P, Kone A. 2009. Health impacts of small reservoirs in Burkina Faso. International Water Management Institute. 50p. DOI:10.3910/2009.202.

Boungou M, Sinaré Y, Mano K, Kabré GB. 2013. Parasitic Copepods (Arthropoda, Crustacea, Copepoda) from Fishes in Burkina Faso, Africa. Int. J. Fish. Aquat. Sci., 2(3): 58-64.

Cecchi P, Meunier-Nikiema A, Moiroux NS, Bougaire F. 2007. Why an Atlas of Lakes and Reservoirs in Burkina Faso? AfricaGIS, 20p.

Da N, Ouedraogo R, Oueda A. 2018. Relation poids-longueur et facteur de condition de Clarias anguillaris et Sarotherodon galilaeus pêchées dans le lac Bam et le réservoir de la Kompienga au Burkina Faso. Int. J. Biol. Chem. Sci., 12(4): 1601-1610.

DOI: https://dx.doi.org/10.4314/ijbcs.v12i4.8

Froese R, Pauly D. 2019. FishBase. World Wide Web electronic publication. www.fishbase.org

Kaboré I. 2016. Benthic invertebrate assemblages and assessment of ecological status of water bodies in the Sahelo Soudanian area (West Africa, Burkina Faso). Doctoral Thesis, University of Natural Resources and Life Sciences, Vienna Austria, p. 202.

Kabré GB, Sakiti NG, Marques A, Sawadogo L. 2002. Thelohanellus bicornei n.sp., Myxosporidie (Myxo sporea, Bivalvulida) Parasite des branchies de Labeo coubie Rüppel, 1832 (Osteichthyen, Cyprinidae) au Burkina Faso, Afrique de l'Ouest. Parasite, 9: 219-223. DOI : http://dx.doi.org/10.1051/parasite/20020 93219.

Lalèyè $\mathrm{P}$, Chikou A, Philipart JC, Teugels G, Vandewalle P. 2004. Étude de la diversité ichtyologique du bassin du fleuve Ouémé au Bénin (Afrique de l'ouest). Cybium, 28 (4): 329-339.

Lévêque C, Paugy D. 2006. Les Poissons des Eaux Continentales Africaines : Diversité, Ecologie et Utilisation par l'Homme. IRD: Paris.

Melcher AH, Ouédraogo R, Schmutz S. 2012. Spatial and seasonal fish community patterns in impacted and protected semiarid rivers of Burkina Faso. Ecol. Eng., 48: $117-129 . \quad$ DOI: 10.1016/j.ecoleng.2011.07.012.

Meulenbroek P, Stranzl S, Oueda A, Sendzimir J, Mano K, Kabore I, Ouedraogo R, Melcher A. 2109. Fish Communities, Habitat Use, and Human Pressures in the Upper Volta Basin, Burkina Faso, West Africa. 
Sustainability, 11(19): 5444-5464; DOI:10.3390/su11195444.

Montchowui E, Chikou A, Kogbeto M-J, Laleye P. 2008. Biodiversité et structure des communautés de poissons du lac Hlan au Bénin. Int. J. Biol. Chem. Sci., 2(2): 196-206. DOI: http://dx.doi.org/10.4314/ijbcs.v2i2.3973 3.

N'Zi KG, Yao SS, Gooré BG, Ndouba V. 2015. Update of ichthyofauna diversity and ecological status of a coastal River Nero (Côte d'Ivoire - West Africa). Saudi Journal of Biological Sciences, 22 : 265-273. DOI: 10.1016/j.sjbs.2014.11.007.

Ouédraogo R, Soara AE, Ouéda A. 2015a. Description du peuplement piscicole du lac sahélien de Higa, un site Ramsar du Burkina Faso, Afrique de l'Ouest. Journal of Applied Biosciences, 95: 8958-8965.

DOI: http://dx.doi.org/10.4314/jab.v95i1.5.

Ouédraogo R, Soara AE, Zerbo H. 2015b. Caractérisation du peuplement piscicole du réservoir de Boalin, Ziniaré (Burkina Faso) deux décennies après l'introduction de Heterotis niloticus. Int. J. Biol. Chem. Sci., 9(5): 2488-2499. DOI:

http://dx.doi.org/10.4314/ijbcs.v9i5.20.

Ouédraogo RB, Sanogo S, Palenfo JS, Kabré JAT. 2019. Etude comparée de l'âge et de la croissance du dipneuste africain Protopterus annectens (Owen 1839, Protopteridea) en état d'hibernation et de non hibernation au Burkina Faso. Int. J. Biol. Chem. Sci., 13(2): 759-775. DOI: https://dx.doi.org/10.4314/ijbcs.v13i2.15

Ouédraogo R. 2010. Fish and fisheries prospective in arid inland waters of Burkina Faso, West Africa. Doctoral thesis, University of Natural Resources and Life Sciences, Vienna, Austria, p. 222 .
Ouédraogo O, Amyot M. 2013. Mercury, arsenic and selenium concentrations in water and fish from sub-Saharan semiarid freshwater reservoirs (Burkina Faso). Science of The Total Environment, 444: 243-254. DOI: https://doi.org/10.1016/j.scitotenv.2012.1 1.095 .

Ouéda A, Guenda W, Ouattara A, Gourène G, Hugueny B, Kabré GB. 2008. Seasonal diet shift of the most important fish species in a sahelo/soudanian reservoir (Burkina Faso). Journal of Fisheries and Aquatic Science, 3 (4): 240-251. DOI: 10.3923/jfas.2008.240.251.

Paugy D, Fermon Y, Abban KE, Diop ME, Traoré K. 1999. Onchocerciasis Control Programme in West Africa: a 20-year monitoring of fish assemblages; Aquat. Living Resour., 12(6): 363-378. DOI:10.1016/S0990-7440(99)00109-6.

Paugy D. 1980. Écologie et biologie des Alestes nurse Pisces, Characidae des rivières de Côted'Ivoire. Cah. Orstom, sér. Hydrobiol., 13: 143-159.

Paugy D, Lévêque C, Teugels GG. 2003b. Poissons d'Eaux Douces et Saumâtres de l'Afrique de l'Ouest, Tome 2. IRD: Paris.

Paugy D, Lévêque C, Teugels GG. 2003a. Poissons d'Eaux Douces et Saumâtres de l'Afrique de l'Ouest, Tome 1, IRD: Paris.

Pouilly M, Pérez T, Rejas D, Guzman F, Crespo G, Duprey J-L, Guimaraes J-RD. 2012. Mercury bioaccumulation patterns in fish from the Ite'nez river basin, Bolivian Amazon. Ecotoxicol. and Environ. Saf., 83 : 8-15. DOI : 10.1016/j.ecoenv.2012.05.018.

Roman FSCB. 1966. Les poissons des HautsBassins de la Volta. Annales - Série IN/8 ${ }^{\circ}$ / Sciences Zoologiques / $\mathrm{N}^{\circ} 150$. Musée Royale de l'Afrique Centrale. Tervuren. Belgique. 191 p. 
Root RB. 1967. The niche exploitation pattern of the blue-gray gnatcatcher. Ecol. Monogr., 37(3): 17-50. DOI: 10.2307/1942327.

Sirima O, Toguyeni A, Kaboré-Zoungrana CY. 2009. Faune piscicole du bassin de la Comoé et paramètres de croissance de quelques espèces d'intérêt économique. Int. J. Biol. Chem. Sci., 3(1): 95-106. DOI:

http://dx.doi.org/10.4314/ijbcs.v3i1.4274 0 .

Stranzl S. 2014. Quantification of human impacts on fish assemblages in the Upper Volta catchment, Burkina Faso. Master Thesis, University of Natural Resources and Life Sciences, Vienna, Austria, p. 90.

Vörösmarty CJ, McIntyre PB, Gessner MO, Dudgeon D, Prusevich A, Green P,
Glidden S, Bunn SE, Sullivan CA, Liermann CR, Davies PM. 2010. Global threats to human water security and river biodiversity. Nature, 467: 555-561. DOI: 10.1038/nature09549.

Quarcoopome TF, Amevenku F, OforiDanson PK. 2011. Changes in the fish community of the Kpong Headpond, lower Volta River, Ghana after 25 years of impoundment. Rev. Biol. Trop. Int. J. Trop. Biol., 59 (4): 1685/1696. DOI: 10.15517/rbt.v59i4.3431.

Witte F, Wanink JH, Kishe-Machumu MA, Rensing M, Goldschmidt T. 2012. Cichlid species diversity in naturally and anthropogenically turbid habitats of Lake Victoria, East Africa. Aquat. Sci., 75: 169-183. DOI: 10.1007/s00027-0120265-4. 